Research Article

\title{
Study of Hydrolysis Process from Pineapple Leaf Fibers using Sulfuric Acid, Nitric Acid, and Bentonite Catalysts
}

\author{
Bayu Wiyantoko*, Rika Rusitasari, Rahma Novia Putri \\ Diploma Program of Chemical Analysis, Chemistry Department, Universitas Islam Indonesia, \\ Yogyakarta 55584, Indonesia.
}

Received: $4^{\text {th }}$ February 2021; Revised: 22 $2^{\text {nd }}$ May 2021; Accepted: $2^{\text {nd }}$ May 2021

Available online: 28th May 2021; Published regularly: September 2021

\section{Abstract}

The hydrolysis process of pineapple leaf fibers has been carried out using sulfuric acid, nitric acid, bentonite catalyst, and activated bentonite catalyst. The sugar content of the hydrolysis product was identified using the phenolsulfuric acid method by UV-Visible spectrophotometry. The disposal of pineapple leaf is a big problem even though it has high cellulose content (70-80\%) and very promising to produce sugar by hydrolysis process. The purpose of this experiment was to determine the effectiveness of homogeneous and heterogeneous catalysts related to sugar levels in pineapple leaf fiber. The variables in this study were the sampling time during the hydrolysis process at a temperature of $100{ }^{\circ} \mathrm{C}$ and the addition of homogeneous and heterogeneous catalysts. The homogeneous catalysts were sulfuric acid and the nitric acid meanwhile heterogeneous catalyst was thermally activated bentonite and acid-activated bentonite. The results obtained highest sugar content reached at 150 minutes using chemical activated bentonite catalysts at $6.459 \mathrm{~g} / \mathrm{L}$ and the addition of catalysts affected sugar yields, speed up the reaction, bentonite as a good catalyst, and gave good prospect for ethanol production in further process.

Copyright (C) 2021 by Authors, Published by BCREC Group. This is an open access article under the CC BY-SA License (https://creativecommons.org/licenses/by-sa/4.0).

Keywords: pineapple leaf fiber; hydrolysis; bentonite catalysts; kinetics

How to Cite: B. Wiyantoko, R. Rusitasari, R.N. Putri (2021). Study of Hydrolysis Process from Pineapple Leaf Fibers using Sulfuric Acid, Nitric Acid, and Bentonite Catalysts. Bulletin of Chemical Reaction Engineering \& Catalysis, 16(3), 571-580 (doi:10.9767/bcrec.16.3.10281.571-580)

Permalink/DOI: https://doi.org/10.9767/bcrec.16.3.10281.571-580

\section{Introduction}

Pineapple (Ananas comosus L. Merr) is one type of fruit whose marketing is fairly evenly distributed in regions of Indonesia. Pineapple production in Indonesia amounted to $1,882,806$ tons and the focus of plant cultivation is from the fruit while the other parts become the residual waste, such as: the leaf, pulp, skin, and peel. Pineapple skin waste produced from one pineapple fruit ranges from $21.73-24.48 \%$, so that the pineapple skin waste produced can reach 40-50 $\mathrm{kg} /$ day. Pineapple leaf is used for animal feed

\footnotetext{
* Corresponding Author

Email: bayuwiyantoko@uii.ac.id (B. Wiyantoko);

Telp: +62-274-895920
}

although it is not known considered due to high fiber content, high soluble carbohydrate, and low protein content [1]. Pineapple leaves are the most widely produced waste from pineapple farming, which is around $90 \%$ of each harvest, and each time a pineapple harvest produces waste consisting of $1 \%$ stems, $9 \%$ stem shoots, and $90 \%$ leaves. This becomes a consideration of utilizing pineapple leaf as a lignocellulose source that other parts of residues. Pineapple leaf contain $69.5-71.5 \%$ cellulose and $4.4-4.7 \%$ lignin [2], while there are $69.5-71.5 \%$ cellulose in pineapple leaf fiber [3].

Pineapple leaf fiber waste has not been optimally used although it was a potential biomass source due to high cellulose content for generat- 
ing reducing sugar through a hydrolysis process to be fermented into ethanol or other value-added products [4]. Cellulose can be hydrolyzed into sugar monomers both chemically with acid solution and enzymatic compounds with cellulase enzyme [5]. Both of these technologies that are often used still have technical constraints namely the price of enzymes that are expensive and vulnerable to changes in operating conditions. While acid hydrolysis is corrosive and causes waste, so it is needed to develop new technologies to improve technical problems, one of which is the heterogeneous catalyst.

The process of hydrolysis made from lignocellulose that has been carried out includes hydrolysis of water hyacinth and rice husk using sulfuric acid to produce reducing sugar 23.3 $\mathrm{mg} / \mathrm{g}$ [6]. Pineapple leaves with hydrochloric acid $(\mathrm{HCl})$ catalyst of $0.3 \mathrm{~N}$ produce the highest glucose levels, 8.958-9.594\% [7]. Hydrolysis of weeds (Imperata cylindrica) with sulfonated activated carbon catalyst resulted in a glucose level of $87.2 \%$ [8], while another report used similar substrate hydrolyze using $2 \%$ sulfuric acid at $140{ }^{\circ} \mathrm{C}$ generated $5.0675 \%$ alcohol [9]. The main advantages of hydrolysis with dilute acid were no need for acid recovery and no loss of acid in the process [10]. The acid used is generally $\mathrm{H}_{2} \mathrm{SO}_{4}$ or $\mathrm{HCl}$ in the $2-5 \%$ concentration range [11].

In this study, pineapple leaf fiber was used in the hydrolysis process using the refluxing method with the assistance of a homogeneous and heterogeneous catalyst for the conversion of lignocellulose into total sugar. The results of

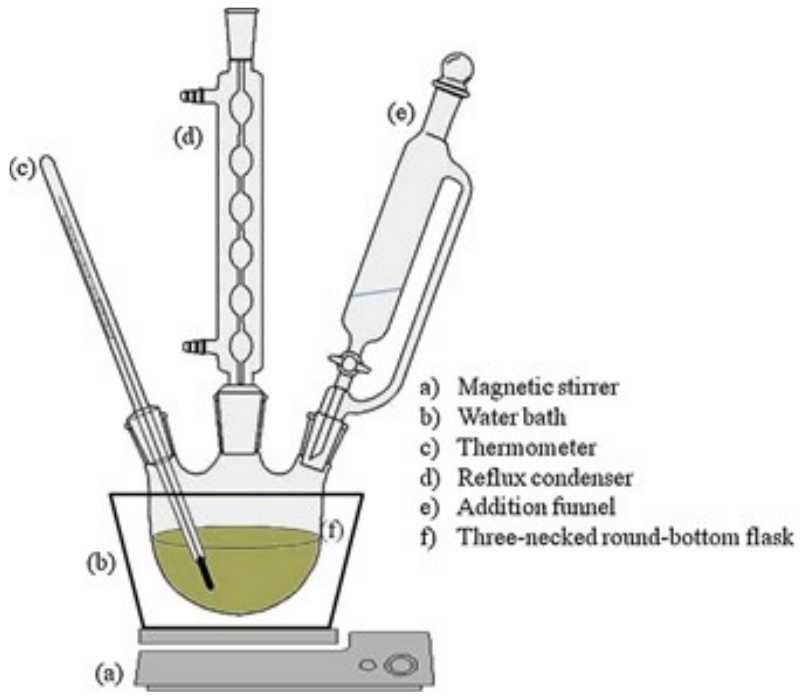

Figure 1. Scheme of hydrolysis process using reflux. this study are expected to be used as a basis for developing pineapple leaf fiber into total sugar and figure out the effectiveness of sulfuric acid, nitric acid, and bentonite as a catalyst in hydrolysis processes based on the total sugar concentration and rate of reaction.

\section{Materials and Methods}

\subsection{Materials}

All reagents used were analytical grades from Merck such as concentrated sulfuric acid, concentrated nitric acid, phenol, and glucose standard. Pineapple leaves as raw material, and sodium bentonite from PT Tunas Inti Makmur Semarang. The equipment used was a set of reflux equipment, oven (Memmert UN55), furnace (Themolyne), analytical balance (Ohaus PA214), glassware, and UVVisible spectrophotometer Thermo scientific GENESYS 20. The scheme of the hydrolysis process is described in Figure 1.

\subsection{Sample Preparation}

Pineapple leaf fiber weighed 20 grams added $200 \mathrm{~mL}$ distilled water and added to the chemical activated natural bentonite weighing 2.5 grams. The sample was put into a threeneck flask and refluxed for 3 hours at $100{ }^{\circ} \mathrm{C}$. Variations of time sampling during the hydrolysis process are 30,60, 90, 120, and 150 minutes. The hydrolysis solution was taken and analyzed at glucose level using the UVVisible spectrophotometer at wavelengths of $480 \mathrm{~nm}$ and $490 \mathrm{~nm}$. The same procedure was repeated for the hydrolysis process using $18 \%$ of $\mathrm{H}_{2} \mathrm{SO}_{4}$ and $12 \%$ of $\mathrm{HNO}_{3}$, no catalyst as a control system, and bentonite for both physical and chemical treatment. The activation of solid catalysts respectively was bentonite put into a furnace for 4 hours at $400{ }^{\circ} \mathrm{C}$ and refluxing bentonite in $18 \%$ of $\mathrm{H}_{2} \mathrm{SO}_{4}$.

\subsection{Analysis of Total Sugar}

The preparation of a standard glucose solution is made by diluting the $100 \mathrm{mg} / \mathrm{L}$ glucose mother solution to a concentration of 0.005 , $0.015,0.020,0.030,0.040$ and $0.05 \mathrm{mg} / \mathrm{mL}$. Furthermore, each $1 \mathrm{~mL}$ standard solution was added $1 \mathrm{~mL} 5 \%$ phenol, shaken, and added 5 $\mathrm{mL}$ of concentrated sulfuric acid solution quickly by pouring perpendicularly to the surface of the solution. The solution is allowed to stand for 10 minutes, beaten then placed in a bath filled with warm water for 15 minutes. Absorbance measurements were performed us- 
ing a UV-Visible spectrophotometer at $480 \mathrm{~nm}$ and $490 \mathrm{~nm}$.

The $1 \mathrm{~mL}$ hydrolysate solution and $1 \mathrm{~mL}$ phenol $5 \%$ were shaken then added $5 \mathrm{~mL}$ of concentrated sulfuric acid quickly by pouring perpendicularly to the surface of the solution. The solution is allowed to stand for 10 minutes and shake again before placed in a water bath for 15 minutes. Absorbance measurements were performed using a UV-Visible spectrophotometer at a similar wavelength as glucose standard solution [12].

\subsection{Kinetic Study}

The kinetic study was measured based on experimental results of the various time of the hydrolysis reaction $(30,60,90,120$, and 150 minutes). Based on these data, the studies of kinetic were calculated by zeroth-order reaction, $1^{\text {st }}$ order reaction, and $2^{\text {nd }}$ order reaction models.

\section{Results and Discussion}

\subsection{Analysis of Total Sugar}

Almost all types of natural fibers, specifically derived from plants (vegetable fibers) like pineapple leaves have the biggest chemical fiber is cellulose, even though it is an element or other substances also found in these fibers, for example, fats and wax, hemicellulose, lignin, and pectin. Fiber obtained from young pineapple leaves has relatively low strength and shorter fiber compared to fiber from old leaves. Pineapple fiber consists of cellulose and noncellulose obtained through mechanical removal of the outer layer of leaves. Cellulose is one of the chemical compositions in pineapple leaves that has the highest content. Cellulose $\left(\mathrm{C}_{6} \mathrm{H}_{10} \mathrm{O}_{5}\right)_{\mathrm{n}}$ is a long-chain polymer of carbohydrate polysaccharides, from B-glucose. Cellulose is one of the main components of lignocellulose which consists of D-glucose monomer units that are bound to 1,4-glycosidic bonds. Cellulose

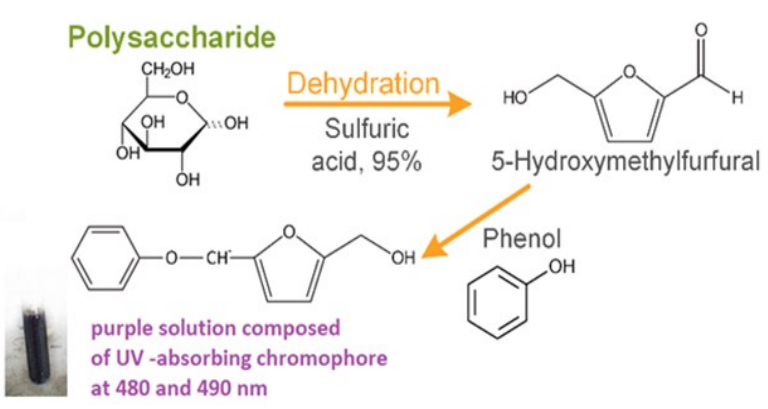

Figure 2. Schematic overview of total sugar analysis (modified from [11]). tends to form microfibrils through inter and intramolecular bonds thus providing a soluble structure. The chemical composition of pineapple fiber is listed in Table 1.

About $69-71 \%$ of cellulose found in pineapple fiber was the main source of sugar production which through enzymatic follow-up treatment will produce ethanol. The abundant cellulose fiber in pineapple leaves will be hydrolyzed in a dilute acid solution or with the help of a solid acid catalyst while pentosan (which is part of hemicellulose) and lignin will inhibit the hydrolysis reaction because resistant to chemicals. Total sugar that was produced from the hydrolysis process of cellulose and hemicellulose can be measured using various methods that are frequently performed by several colorimetric procedures. Most methods involve colorimetric detection based on the oxidation of the carbonyl groups followed by reaction with a UV-Visible absorbing molecule. The wellknown method was phenol-sulfuric acid for determining sub-micro amounts of sugars and related substances due to good sensitivity, low analysis cost, easy handling, and accessible equipment although it requires a high concentration of hazardous sulfuric acid and a wide range of analytical wavelengths for measurement. This method used a 5\% phenol solution and concentrated sulfuric acid which is added after the hydrolysis results of pineapple leaf fibers and after 15 minutes of cooling into room temperature to help the process of color formation (complexing reaction) becoming stable as described in Figure 2.

The sulfuric acid causes the hydrolysis of the glycosidic links and the dehydration of the released monosaccharides to form furfural derivatives which react with the phenol and give the orange color to the solution. The total sugar content from pineapple leaf fiber was quite high so it resulted in purple color as the final solution. The color produced by furfural methyl hydroxy varies from green, orange, brown, and

Table 1. Chemical composition of pineapple fiber [3].

\begin{tabular}{ll}
\hline Composition & Amount (\%) \\
\hline$\alpha$-cellulose & $69.5-71.5$ \\
Pentosan & $17-17.8$ \\
Lignin & $4.4-4.7$ \\
Pectin & $1-1.2$ \\
Fat and wax & $3-3.3$ \\
Ash & $0.71-0.87$ \\
Other substances & $4.5-5.3$ \\
\hline
\end{tabular}


purple depending on the concentration of glucose possessed by the sample. The measurement of hydrolysate products of pineapple leaf fiber at two different wavelengths due to each sugar has its maximum absorption related to the structure it is own. Each hydrolysate from the hydrolysis process with the addition of homogeneous and heterogeneous catalysts was calculated by extrapolating the absorbance value into the regression equation from the standard series of glucose as presented in Figure 3.

For the hydrolysis of pineapple leaf fibers using homogeneous catalysts, the total sugar content is different from heterogeneous catalysts where sulfuric acid catalysts can compete with heterogeneous catalysts compared to nitric acid catalysts. For the duration of the hydrolysis time of 150 minutes, the sulfuric acid catalyst was able to compete with a chemical activated catalyst with a total sugar content of $6.387 \mathrm{~g} / \mathrm{L}$ even though chemical activated catalyst appeared dominant until the end of the hydrolysis time duration with a total sugar acquisition of $6.459 \mathrm{~g} / \mathrm{L}$. Optimal levels of total sugar of pineapple leaf fibers with a sulfuric acid catalyst and nitric acid catalyst at 150 minutes and did not increase significantly from 120 minutes to 150 minutes caused by degradation to side products such as furfural, 5hydroxymethylfurfural (HMF), levulinic acid, acetic acid, formic acid, uronic acid, and so on.
These results are consistent with the previous study that hydrolysis time besides acid concentration and hydrolysis temperature plays an important role in the acquisition of total sugar content (in this case glucose) the hydrolysis of pineapple leaves [14]. Sulfuric acid catalysts produce more total sugar levels because it has higher acidity than nitric acid which is related to the value of acid dissociation constant where pKa $\mathrm{HNO}_{3}>$ pKa $\mathrm{H}_{2} \mathrm{SO}_{4}$ made sulfuric acid could contribute more protons in aqueous solution. At the same hydrolysis time and concentration, sulfuric acid can break the hydrogen bonds until it reaches the amorphous and crystalline cellulose networks into oligosaccharide and monosaccharide molecules [15]. This is in line with the results of the hydrolysis of sago pulp waste using a sulfuric acid catalyst capable of producing a greater percentage of cellulose $(59.51 \%)$ with a small difference in the percentage of yield (42.88\%) compared to a stronger chloride acid catalyst (42.91\%) [16]. Total sugar levels obtained from the use of sulfuric acid and nitric acid catalysts have decreased with the length of hydrolysis due to the process of sugar degradation and the formation of side products, such as: furfural, 5-hydroxymethylfurfural (HMF), levulinic acid, acetic acid, formic acid, uronic acid, and so on [17]. These results are in line with the previous report that using pineapple leaves for the hy-

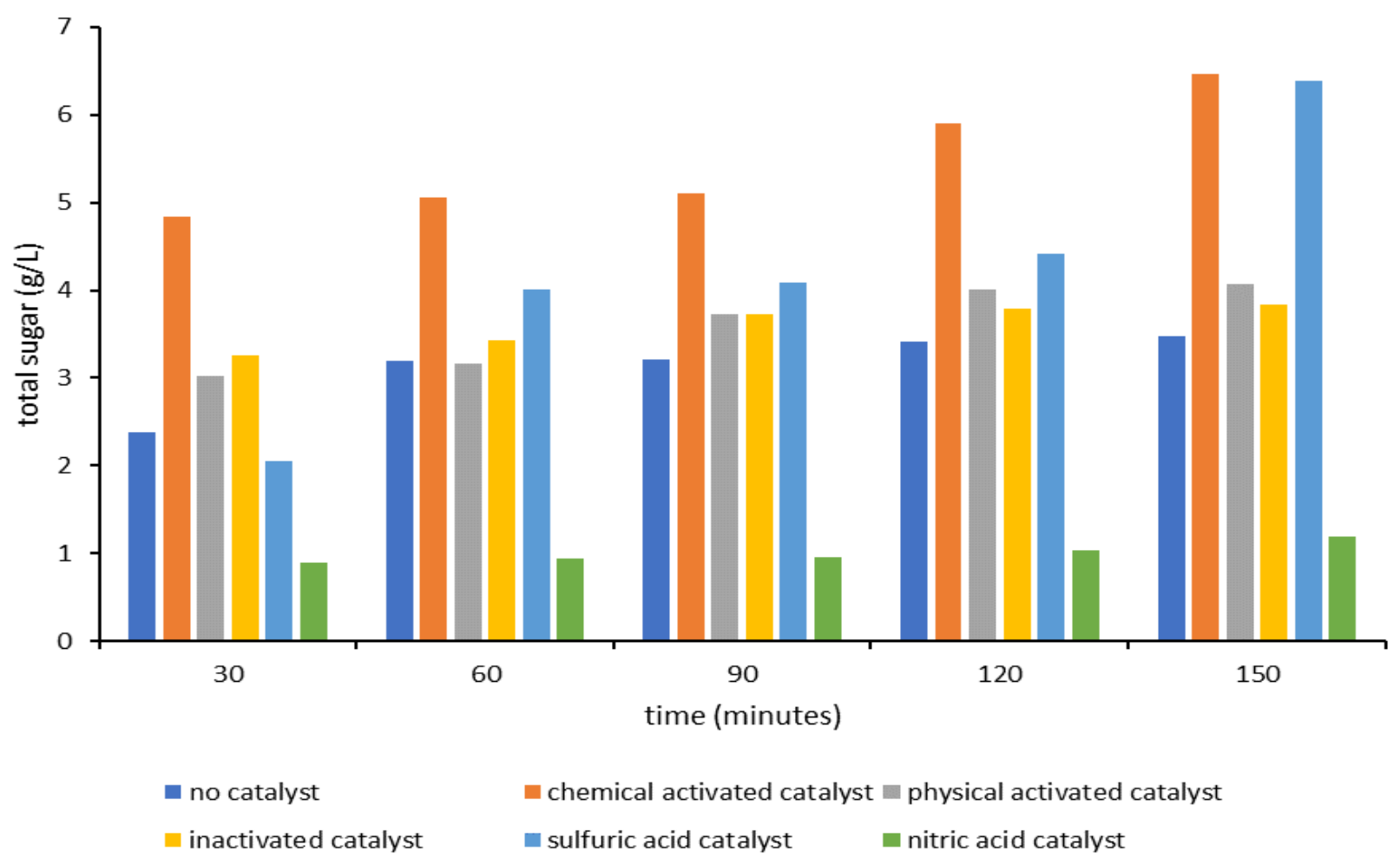

Figure 3 . The total sugar content of hydrolysate. 
drolysis process with a sulfuric acid solution at various concentrations (1-5\%) and hydrolysis time (30-120 minutes) [18] and also the usage of catalyst $\mathrm{HCl}$ solution $(0.1-0.3 \mathrm{~N})$ at temperatures of $30{ }^{\circ} \mathrm{C}$ and $80^{\circ} \mathrm{C}$ up to 360 minutes for hydrolysis of pineapple skin [7].

Meanwhile, for the hydrolysis process using heterogeneous catalysts in the form of natural bentonite, physically activated bentonite, and chemical activated bentonite give good results and can compete with homogeneous catalysts. The hydrolysis process without the presence of a maximum catalyst produced a total sugar level of $3.48 \mathrm{~g} / \mathrm{L}$ for 150 minutes which was able to obtain natural clay catalysts $(3.43 \mathrm{~g} / \mathrm{L})$ with a duration of hydrolysis time of 60 minutes.

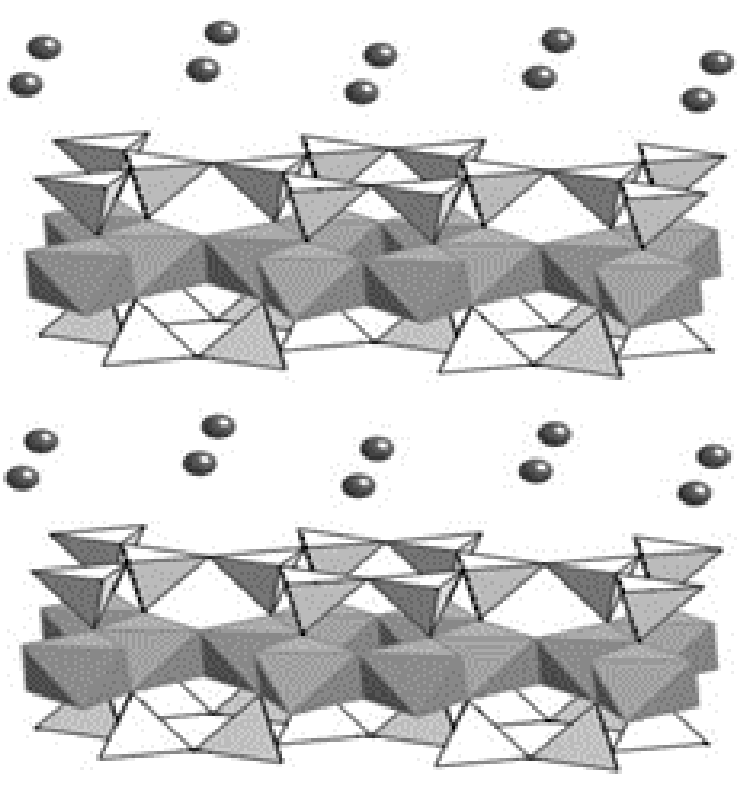

Figure 4. Structure of montmorillonite [19].
These results indicate that the catalyst solids help the hydrolysis process of pineapple leaf cellulose fibers become faster due to the acidity characteristics possessed by the catalyst. The heterogeneous catalyst used is the bentonite in a 2:1 configuration that has each aluminumcontaining layer covalently bound above and below by a silicon-containing layer; this prevents active sites from interacting with the cellulose. The octahedra are $\mathrm{AlO}_{6}$ units and the tetrahedra are $\mathrm{SiO}_{4}$ units. The sheets in bentonite are charged due to $\mathrm{Al}: \mathrm{Si}$ imbalance. The sheets are held together by ionic forces between the sheets and a cation (dark sphere) as described in Figure 4.

The process of cellulose hydrolysis in pineapple leaf fibers using a solution of sulfuric acid and nitric acid through the cleavage mechanism of B-1-4-glycosidic bonds takes place in three stages: the protons in the acid solution interact rapidly with oxygen (in the glycosidic bonds) to form acids the conjugate which then occurs by breaking the $\mathrm{CO}$ bonds and the conjugate acid into a cyclic carbonium ion as presented in Figure 5. The addition of fast water solvents in large quantities will release sugars and protons, where the process of breaking the glycosidic bonds is faster at the ends than in the middle of the polysaccharide chain [20]. Sulfuric and nitric acid catalysts used in this study were $18 \%$ and $11 \%$ respectively so that the rate of hydrolysis of pineapple leaf cellulose was slow because the catalyst concentration factor was very influential where concentrations above $65 \%$ were able to produce a hydrolysis rate twice as large so that it could produce a more optimal total sugar content. The water solvent hydrolysis system without $\mathrm{pH}$ control makes the water act as a weak acid which

$\mathrm{I} \mathrm{HX}+\mathrm{H}_{2} \mathrm{O} \rightleftharpoons \mathrm{H}_{3} \mathrm{O}^{+} \mathrm{X}^{-}$

II

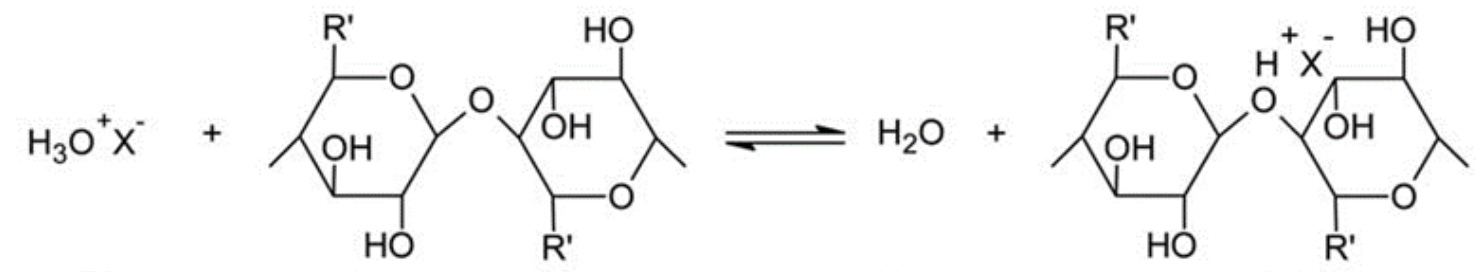

III
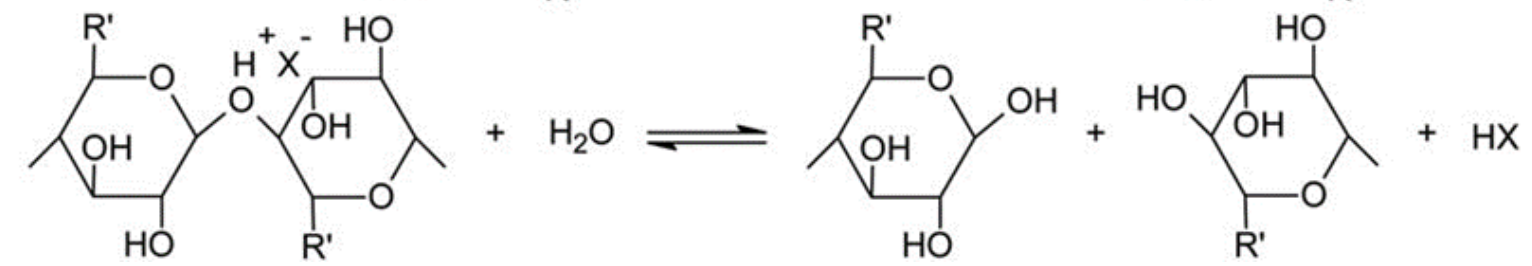

Figure 5. The mechanism of homogeneous acid-catalyzed cellulose hydrolysis [21]. 
quickly releases protons for the hydrolysis of polysaccharides into monosaccharides.

The acidity of bentonite clay is obtained from the active sites of Brönsted and Lewis which play a role in the hydrolysis of pineapple leaf cellulose fibers. To increase the catalytic ability of the bentonite catalyst the physical activation step was carried out through a calcination process at $600{ }^{\circ} \mathrm{C}$ for 4 hours and chemical activation using sulfuric acid. Hightemperature heating increases the number of acid sites due to the formation of unsaturated $\mathrm{Al}^{3+}$ ions for Lewis acid and $\mathrm{H}_{3} \mathrm{O}^{+}$ions which combine with $\mathrm{AlO}_{4}$ in the tetrahedral layer where the highest amount is obtained when heating temperatures to $120^{\circ} \mathrm{C}$ as reported by [22]. Meanwhile, chemical activation with sulfuric acid causes balancing cations, such as $\mathrm{Na}^{+}$, disappears and the structural changes occur because the number of dissolved $\mathrm{Al}$ ions makes the acidity level is low to moderate [23]. Table 2 showed the acidity value of bentonite catalyst was measured using the old fashion method which is ammonia-gravimetric. It is seen that activation of bentonite catalyst can increase the acidity and further enhance the catalytic process of cellulose hydrolysis.

Figure 6 presented the shifted band of infrared spectrum from raw and treated bentonite. Acid treatment on chemical activated bentonite has given a significant effect on remove water from the structure indicated by a less intense band at $3630 \mathrm{~cm}^{-1}$ and $1638 \mathrm{~cm}^{-1}$ also the band at $3435 \mathrm{~cm}^{-1}$ disappeared. These phenomena also emerge on treated bentonite by heating or physical process. There is also a decrease in the intensity of the band at $524 \mathrm{~cm}^{-1}(\mathrm{Si}-\mathrm{O}$ deformation) of treated samples compared to raw bentonite showed the affected of a tetrahedral

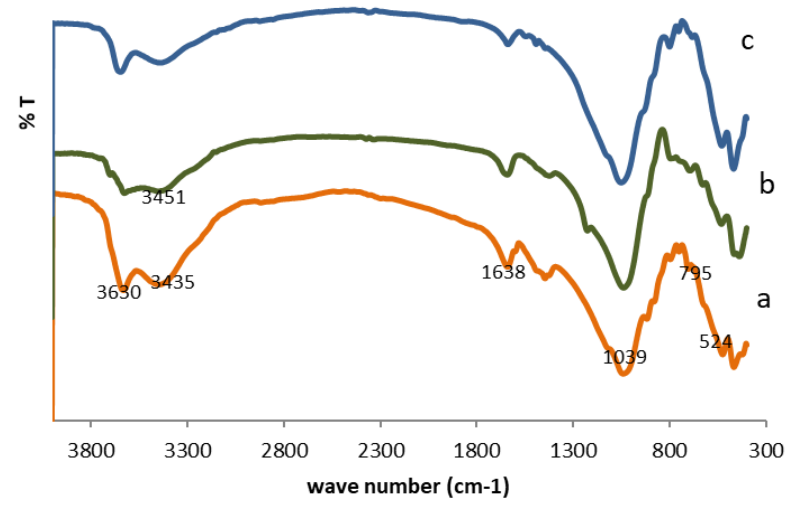

Figure 6. The infrared spectrum of (a) raw bentonite (b) physical activated bentonite and (c) chemical activated bentonite. structure by acid treatment [23]. The bands around $3400 \mathrm{~cm}^{-1}$ for all samples were still seen indicated adsorbed water was desorbed by $\mathrm{NH}_{3}$ adsorption, where interlayer water reacted with $\mathrm{NH}_{3}$ forming $\mathrm{NH}_{4}{ }^{+}$ions or also reacted with Lewis and Brönsted acid sites. The characteristic bands of hydrogen-bond ammonia were not observed due to overlap with the bands of $\mathrm{NH}_{4}{ }^{+}$and $\mathrm{NH}_{3}$ [22].

In general, the acid activation and heating effect increase the specific surface area of the bentonite. Hydrolysis of bentonite with acids disrupt the layered structure of the bentonite due to the aluminum oxide layer is attacked so that it dissolves some aluminum and other elements in the octahedral layer. The release of $\mathrm{Al}$ octahedral cations from the bentonite structure opens the structure with a distribution of one sheet of pore size, so that the relative acidity of the bentonite increases.

Brönsted acid sites originate from protons bound to siloxane ( $\mathrm{Si}-\mathrm{O}-\mathrm{Si}$ ) groups, while Lewis acid comes from $\mathrm{Al}$ metals from the octahedral groups that make up natural bentonite. The bentonite catalyst in this study still needs further comprehensive characterization to support acidity information as well as structural changes. Otherwise, the bentonite catalyst supported with Lewis acid improves the cellulose degradation due to $\mathrm{Al}$ as transition metal has numerous empty orbitals which can be occupied by lone pair electrons from oxygen in hydroxyl of cellulose generating the change in reaction mechanism as well as reducing the reaction of energy barrier as shown in Figure 7. A similar mechanism also appeared in a previous study using $\mathrm{CrCl}_{3}$ catalyst for degradation of cellulose into glucose and $\mathrm{HMF}$ in variation temperature among $140^{\circ} \mathrm{C}$ to $170{ }^{\circ} \mathrm{C}$ [24].

Every chemical reaction generates a specific chemical rate which can be a slow or fast reaction and catalysts are one of the factors affecting the chemical rate. The rate measurement based on a relationship between physical properties $(\lambda)$ and concentration is described in Equations (2) and (4). In cellulose hydrolysis of pineapple leaf fiber, the addition of homogeneous and heterogeneous catalysts should be de-

Table 2 . Acidity value of the catalyst.

\begin{tabular}{lc}
\hline Catalyst & $\begin{array}{c}\text { Acidity value } \\
\text { (mmol/g) }\end{array}$ \\
\hline Bentonite & 5.122702 \\
Physically activated bentonite & 6.879196 \\
Chemical activated bentonite & 7.340855 \\
\hline
\end{tabular}




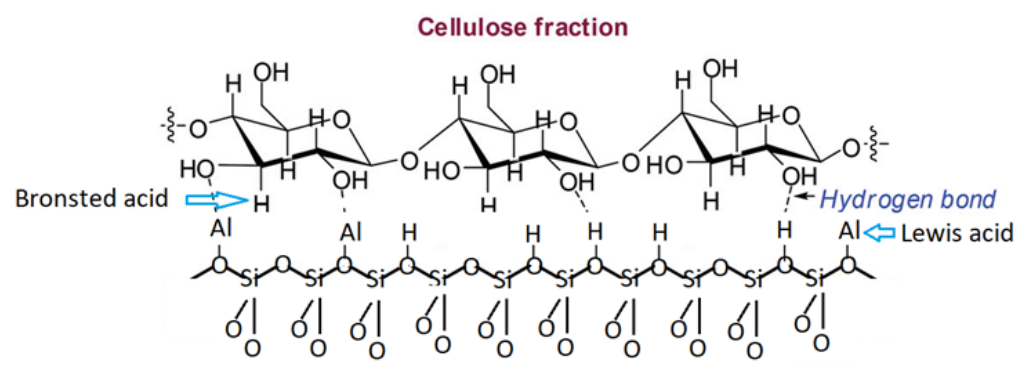

Figure 7. The mechanism of heterogeneous acid-catalyzed cellulose hydrolysis.
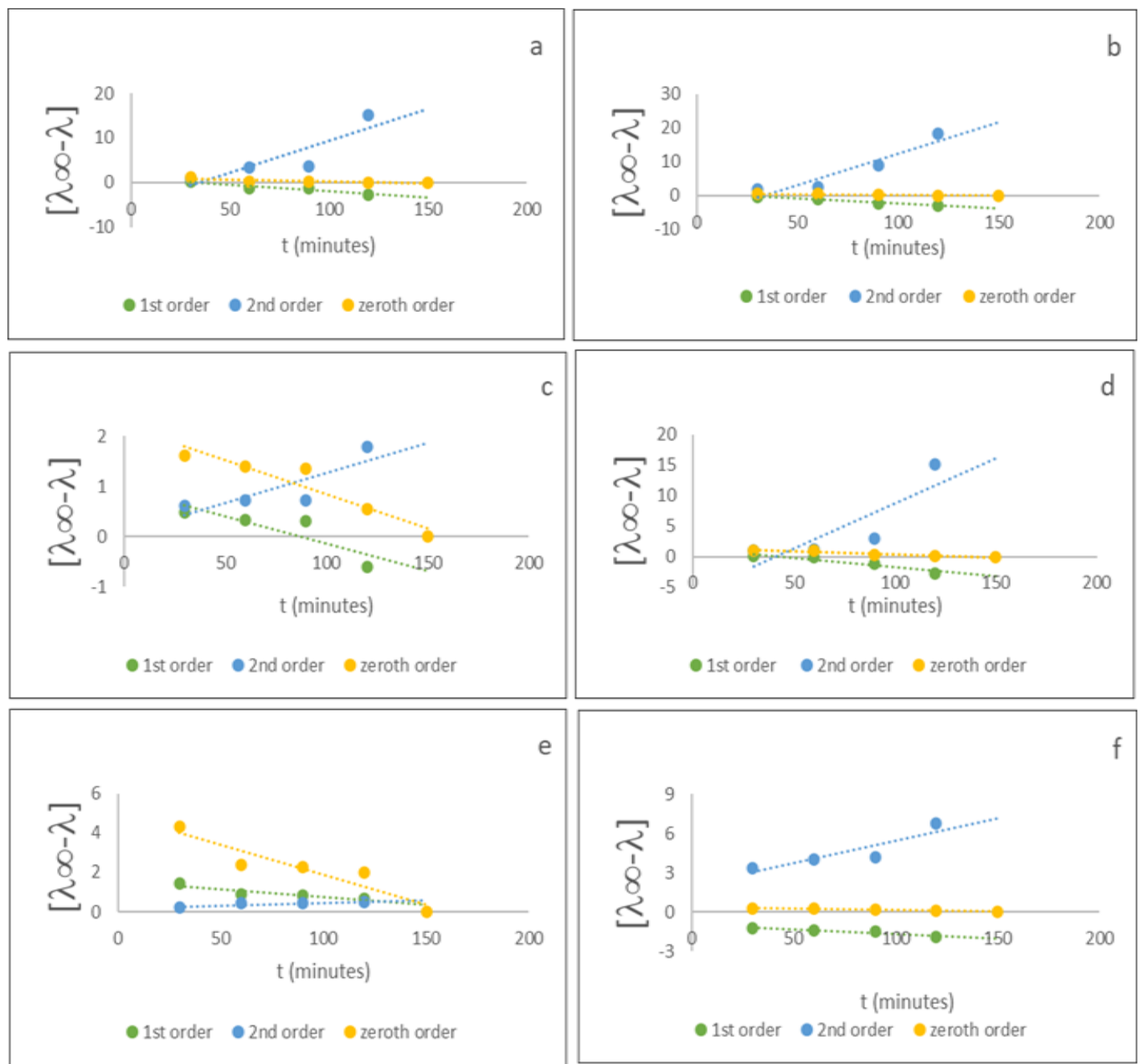

Figure 8. Graphical plot of rate constant at $100{ }^{\circ} \mathrm{C}$ for hydrolysis process with (a) no catalyst (b) inactivated catalyst (c) physical activated catalyst (d) chemical activated catalyst (e) sulfuric acid catalyst (f) nitric acid catalyst.

Table 3. Linearity value from the kinetic model.

\begin{tabular}{lccc}
\hline \multirow{2}{*}{ Type of catalyst } & \multicolumn{3}{c}{$\mathrm{R}^{2}$} \\
\cline { 2 - 4 } & Zeroth order reaction & $1^{\text {st }}$ order-reaction & $2^{\text {nd }}$ order-reaction \\
\hline No catalyst & 0.7584 & 0.9158 & 0.7624 \\
Inactivated bentonite & 0.9084 & 0.9579 & 0.8965 \\
Physically activated bentonite & 0.8915 & 0.7350 & 0.6818 \\
Chemical activated bentonite & 0.9307 & 0.8826 & 0.7100 \\
Sulfuric acid catalyst & 0.8672 & 0.8506 & 0.7948 \\
Nitric acid catalyst & 0.8804 & 0.8657 & 0.8122 \\
\hline
\end{tabular}


termined using the zeroth-order, $1^{\text {st }}$ order, and $2^{\text {nd }}$ order models as described respectively in Equations (1), (2), and (3) with $\lambda_{\infty}$ are physical properties at an infinite time; $\lambda_{t}$ are physical properties at $t=t ; \lambda_{0}$ is physical properties at $t=0 ; t$ is a time of reaction, $A_{o}$ is initial concentration; $A_{t}$ is concentration at $t=t$; and $k$ is the chemical reaction rate constant.

$$
\begin{aligned}
& \lambda_{t}=-k t+\lambda_{0} \\
& \ln \left(\frac{\lambda_{\infty}-\lambda}{\lambda_{\infty}-\lambda_{0}}\right)=-k t \\
& \frac{1}{\lambda_{\infty}-\lambda}-\frac{1}{\lambda_{\infty}-\lambda_{0}}=\frac{A_{0} k t}{\lambda_{\infty}-\lambda_{0}} \\
& A_{t}=A_{0}\left(\frac{\lambda_{\infty}-\lambda}{\lambda_{\infty}-\lambda_{0}}\right)
\end{aligned}
$$

The graphical plot of the relationship between the hydrolysis time (t) towards $\left(\lambda_{\infty}-\lambda\right) ; \ln$ $\left(\lambda_{\infty}-\lambda\right)$ as well as $1 /\left(\lambda_{\infty}-\lambda\right)$ each has a linear regression value $\left(R^{2}\right)$ which varies according to the type of catalyst as described in Figure 8. Based on the linearity values, the usage of homogeneous and activated bentonite catalysts are fitting with the zeroth-order reaction model which meaning the hydrolysis of pineapple leaf fiber was not affected by catalyst concentration. Meanwhile, the presence of inactivated bentonite and the absence of catalyst in the hydrolysis system followed the $1^{\text {st }}$ order reaction model as listed in Table 3.

The hydrolysis of pineapple leaf fibers in this research, with the addition of dilute acid catalyst and the solid acid catalyst, was categorized as a heterogeneous system due to produced higher crystallinity and a lower degree of polymerization of hydro cellulose products. The rate of hydrolysis of cellulose in crystalline form is one to two orders of magnitude lower than that of homogeneous hydrolysis of soluble compounds that can be achieved using a concentrated acid catalyst as listed in Table 4.
Based on the $1^{\text {st }}$ order reaction model, the addition of catalyst particularly activated bentonite was affected in the rate of pineapple leaf fiber hydrolysis and it was also described from zeroth-order reaction even though not quite significant. Meanwhile, the dilute sulfuric acid declined the rate, and on the contrary nitric acid catalysts, raise the rate of the hydrolysis process. The chemical activated bentonite brings a significant rate on hydrolysis reaction and is related to the obtained highest total glucose concentration. The dilute sulfuric acid has a lower rate constant compared to the process with no catalyst due to part of cellulose was reprecipitated and generated a higher hydrolysis rate. A similar result has been reported that $60 \%$ dilute acid or less given lower hydrolysis process due to not much-dissolved cellulose so the breaking of $\beta$-1-4-glycosidic bonds did not reach the optimum level [20]. To determine the $k$ value of cellulose hydrolysis also required the $k$ value of glucose destruction due to cellulose were not completely degraded to form glucose but also another substance. The $k$ value of glucose destruction was obtained from the slope of chosen order reaction model, where a higher $k$ value meaning higher catalyst concentration and temperature used in the hydrolysis process [25]. From Table 4, according to the $1^{\text {st }}$ order reaction model that the involvement of bentonite catalyst on hydrolysis of pineapple leaf fiber gave higher glucose destruction in line with concentration and temperature used in the system.

\section{Conclusion}

In summary, pineapple leaf fiber has good prospects for development as a source of lignocellulosic biomass. The involvement of homogeneous and heterogeneous catalysts gives different results both in total sugar content and in the rate of the hydrolysis reaction. In this research, chemical activated bentonite is the most promising catalyst since generating the highest total glucose, meanwhile nitric acid is

Table 4. Reaction rate constant $(k)$.

\begin{tabular}{lccc}
\hline Type of catalyst system & $k_{0}\left(\mathrm{~mol} \cdot \mathrm{L}^{-1} \cdot \mathrm{s}^{-1}\right)$ & $k_{1}\left(\mathrm{~s}^{-1}\right)$ & $k_{2}\left(\mathrm{~L} \cdot \mathrm{mol}^{-1} \cdot \mathrm{s}^{-1}\right)$ \\
\hline No catalyst & 0.0081 & 0.0284 & 0.1434 \\
Inactivated bentonite & 0.0050 & 0.8360 & 0.1866 \\
Physical activated bentonite & 0.0136 & 0.3240 & 0.0119 \\
Chemical activated bentonite & 0.0097 & 0.9247 & 0.1480 \\
Sulfuric acid catalyst & 0.0302 & 0.0080 & 0.0028 \\
Nitric acid catalyst & 0.0023 & 0.2139 & 0.0346 \\
\hline
\end{tabular}


not a good choice for assisting the hydrolysis reaction of pineapple leaf fiber. The presence of a heterogeneous catalyst and homogeneous catalyst followed the zeroth-order reaction in the hydrolysis of pineapple leaf fiber.

\section{Acknowledgment}

The work was financially supported by the Diploma Program of Chemical Analysis, Universitas Islam Indonesia. Appreciation was delivered to Rika Rusitasari and Rahma Novia Putri for assistance in laboratory work as well as data analysis and also to the laboratory of applied chemistry for providing the research facilities.

\section{References}

[1] Onggo, H., Astuti, J.T. (2005) Pengaruh Sodium Hidroksida dan Hidrogen Peroksida terhadap Rendemen dan Warna Pulp dari Serat Daun Nenas, J. Ilmu Teknol. Kayu Trop., 3(1), 37-43. DOI: 10.51850/jitkt.v3i1.304.g277

[2] Jayanudin, J. (2009). Pemutihan Daun Nanas Menggunakan Hidrogen Peroksida. J. Rekayasa Proses, 3(1), 10-14. DOI: 10.22146/jrekpros.560.

[3] Hidayat, P. (2008). Teknologi Pemanfaatan Serat Daun Nanas Sebagai Alternatif Bahan Baku Tekstil. Teknoin, 13, 31-35. DOI: 10.20885/.v13i2.795

[4] Sun, Y., Cheng, J. (2002). Hydrolysis of lignocellulosic materials for ethanol production: A review. Bioresour. Technol., 83(1), 1-11. DOI: 10.1016/S0960-8524(01)00212-7.

[5] Da Silva, C.N., Bronzato, G.R.F., Cesarino, I., Leão, A.L. (2020). Second-generation ethanol from pineapple leaf fibers. J. Nat. Fibers, 17 ( 1 ), $113-121$. D O I : 10.1080/15440478.2018.1469453.

[6] Wilda, N., Pandebesie, E.S. (2015). Hidrolisis Eceng Gondok dan Sekam Padi untuk Menghasilkan Gula Reduksi sebagai Tahap Awal Produksi Bioetanol. J. Tek. ITS, 4(2), 26. DOI: $10.12962 / j 23373539 . v 4 i 2.11308$

[7] Susanti, A.D., Prakoso, P.T., Prabawa, H. (2011). Pembuatan bioetanol dari kulit nanas melalui hidrolisis dengan asam. Ekuilibrium, $10(2), \quad 81-86 . \quad$ D O I : 10.20961/ekuilibrium.v12i1.24896

[8] Anggoro, D.D., Purwanto, P., Rispiandi, R. (2014). Hidrolisis Selulosa Menjadi Glukosa Dengan Katalis Heterogen Arang Aktif Tersulfonasi. Reaktor, 15(2), 126. DOI: 10.14710/reaktor.15.2.126-131.
[9] Osvaldo Z.S., Panca, P.S., Faizal, M. (2012). Pengaruh Konsentrasi Asam dan Waktu Pada Proses Hidrolisis dan Fermentasi Pembuatan Bioetanol dari Alang-Alang. J. Tek. Kim., 18(2), 52-62.

[10] Iranmahboob, J., Nadim, F., Monemi, S. (2002). Optimizing acid-hydrolysis: A critical step for the production of ethanol from mixed wood chips. Biomass and Bioenergy, 22(5), 401-404. DOI: 10.1016/S0961-9534(02)000168.

[11] Mussatto, S.I., Roberto, I.C. (2004). Alternatives for detoxification of diluted-acid lignocellulosic hydrolyzates for use in fermentative processes: A review. Bioresour. Technol., $93(1), \quad 1-10 . \quad$ D O I : 10.1016/j.biortech.2003.10.005.

[12] Rover, M.R., Johnston, P.A., Lamsal, B.P., Brown, R.C. (2013). Total water-soluble sugars quantification in bio-oil using the phenolsulfuric acid assay. J. Anal. Appl. Pyrolysis, $104, \quad 194-201$. D O I : 10.1016/j.jaap.2013.08.004.

[13] Viel, M., Collet, F., Lanos, C. (2018). Chemical and multi-physical characterization of agro-resources' by-product as a possible raw building material. Ind. Crops Prod., 120, 214-237. DOI: 10.1016/j.indcrop.2018.04.025.

[14] Choojit, S., Ruengpeerakul, T., Sangwichien, C. (2018). Optimization of acid hydrolysis of pineapple leaf residue and bioconversion to ethanol by saccharomyces cerevisiae. Cellul. Chem. Technol., 52(3-4), 247-257.

[15] Huntley, C.J., Crews, K.D., Abdalla, M.A., Russell, A.E., Curry, M.L. (2015). Influence of strong acid hydrolysis processing on the thermal stability and crystallinity of cellulose isolated from wheat straw. Int. J. Chem. Eng., 1, 1-9. DOI: $10.1155 / 2015 / 658163$.

[16] Dewi, A.M.P., Kusumaningrum, M.Y., Pranoto, Y., Darmadji, P. (2017). Ekstraksi dan karakterisasi selulosa dari limbah ampas sagu, Prosiding Seminar Nasional Sains dan Teknologi ke-8, pp. 6-9. Fakultas Teknik Universitas Wahid Hasyim Semarang, Seminar Nasional Sains dan Teknologi.

[17] Taherzadeh, M.J., Karimi, K. (2007). AcidBased Hydrolysis Processes for Ethanol From Lignocellulosic Materials: a Review. BioResources, 2(3), 472-499.

[18] Haryani, N., Novia., Syarief, V.L., Ananda, S.R. (2015). Pengaruh Konsentrasi Asam dan Waktu Hidrolisis Pada Pembentukan Bioetanol Dari Daun Nanas. J. Tek. Kim., 21(4), 3946. 
[19] Hick, S.M., Griebel, C., Restrepo, D.T., Truitt, J.H., Buker, E.J., Bylda, C., Blair, R.G. (2010). Mechanocatalysis for biomass-derived chemicals and fuels. Green Chem., 12, 468474. DOI: $10.1039 / \mathrm{b} 923079 \mathrm{c}$.

[20] Xiang, Q., Lee, Y.Y., Pettersson, P.O., Torget, R.W. (2003). Heterogeneous Aspects of Acid Hydrolysis of a-Cellulose. Appl. Biochem. Biotechnol., 105, 505-514. DOI: 10.1385/ABAB:107:1-3:505.

[21] Salmi, T., Murzin, D. Y., Maki-Arvela, P., Kusema, B., Holmbom, B., Wilfor, S. (2014). Kinetic Modeling of Hemicellulose Hydrolysis in the Presence of Homogeneous and Heterogeneous Catalysts. AIChE J., 60(3), 10661077. DOI: 10.1002/aic.14311

[22] Liu, D., Yuan, P., Liu, H., Cai, J., Qin, Z., Tan, D., Zhou, Q., He, H., Zhu, J. (2011). Influence of heating on the solid acidity of montmorillonite: A combined study by DRIFT and Hammett indicators. Appl. Clay Sci., 52(4), 358-363. DOI: 10.1016/j.clay.2011.03.016.
[23] Bieseki, L., Treichel, H., Araujo, A.S., Pergher, S.B.C., (2013), Porous materials obtained by acid treatment processing followed by pillaring of montmorillonite clays. Appl. Clay Sci., $\quad 85(1), \quad 46-52$. $\quad$ D O I : 10.1016/j.clay.2013.08.044.

[24] Zhang, H., Li, S., Xu, L., Sun, J., Li, J. (2016). Kinetic Study of the Decomposition of Cellulose to 5-Hydroxymethylfurfural in Ionic Liquid. BioResources, 11(2), 4268-4180. DOI: 10.15376/biores.11.2.4268-4280

[25] Tursiloadi, S., Sanjaya, G.K., Indrasti, N.S. (2009). Mathematic Model Of Hydrolysis Process From Banana Trees Cellulose To Glucose By Using Liquid Acid Catalyst. J. Tek. Ind. Pert., 19(3), 164-169.

Selected and Revised Papers from $3^{\text {rd }}$ International Conference on Chemistry, Chemical Process and Engineering 2020 (IC3PE 2020) (https://chemistry.uii.ac.id/ic3pe/) (Universitas Islam Indonesia (UII), Labuan Bajo, Nusa Tenggara Timur, Indonesia by 30th September - $1^{\text {st }}$ October 2020) after Peer-reviewed by Scientific Committee of IC3PE 2020 and Peer-Reviewers of Bulletin of Chemical Reaction Engineering \& Catalysis. Editors: Is Fatimah; I. Istadi. 